\title{
Eutrophication of moderately deep Dutch lakes during the past century: flaws in the expectations of water management?
}

\author{
E. P. Kirilova $\cdot$ H. Cremer $\cdot$ O. Heiri $\cdot$ \\ A. F. Lotter
}

Received: 26 May 2009/Revised: 13 October 2009/Accepted: 10 November 2009/Published online: 25 November 2009

(C) The Author(s) 2009. This article is published with open access at Springerlink.com

\begin{abstract}
We studied the trophic development of the past 30-100 years in eight moderately deep Dutch lakes based on their sedimentary fossil diatom assemblages. The dominant diatoms indicating meso- to eutrophic conditions were Aulacoseira subarctica, Cyclotella ocellata, C. cyclopuncta, C. meneghiniana, Puncticulata bodanica, Aulacoseira granulata, Cyclostephanos dubius, C. invisitatus, Stephanodiscus hantzschii, S. medius, and S. parvus. Ordination of diatom data separated the lakes into four groups according to their total phosphorus concentrations (TP), water supply, water management, and origin. The first group consists of dike-breach lakes, which were in stable eutrophic to hypertrophic conditions throughout the past century with diatom-inferred TP (DI-TP) concentrations of between 70 and $300 \mu \mathrm{g}^{-1}$. The main factors influencing these dike-breach lakes
\end{abstract}

Handling editor: J. Saros

E. P. Kirilova $(\bowtie) \cdot$ H. Cremer · O. Heiri · A. F. Lotter Palaeoecology, Institute of Environmental Biology, Laboratory of Palaeobotany and Palynology, Utrecht University, Budapestlaan 4, 3584 CD Utrecht, The Netherlands e-mail: e.p.kirilova@uu.nl

H. Cremer

Netherlands Organization for Applied Scientific Research TNO, Geological Survey of the Netherlands, Princetonlaan 6, 3584 CB Utrecht, The Netherlands are river management, ground water supply of riverine origin, and local land use. The second group are artificial lakes of fluctuating oligo- to mesotrophic conditions and DI-TP concentrations of 10-30 $\mu \mathrm{g} \mathrm{l}^{-1}$. Only one of the artificial lakes showed a DI-TP increase due to changes in catchment agricultural practice. A third group includes an artificial moat and an inland dike-breach lake with DI-TP concentrations of $50-100 \mu \mathrm{g} \mathrm{l}^{-1}$. The fourth group contains an individual dike-breach lake with stable mesotrophic conditions of $50 \mu \mathrm{g} \mathrm{l}^{-1}$ throughout the past century. Rather than showing a regional pattern, the studied lakes behave very individualistically with regard to their trophic history, reflecting changes in the local hydrology and in their nutrient sources.

Keywords Eutrophication - Diatoms · Total phosphorus reconstruction · Lowland lakes

\section{Introduction}

Eutrophication is a process that occurs during the development of many lakes and rivers (Wetzel, 2001) and represents an increase in primary productivity due to external and internal nutrient input. Due to increased human impact during the past century, eutrophication has substantially increased worldwide and has become a key concern for water quality management (e.g., Carpenter et al., 1999; Walker \& Meyers, 2004; Smol, 2008). 
The ecological and socio-economic consequences of the effect of eutrophication on ecosystem functioning and services have long been recognized. Consequently, legal and management measures against the negative impacts of nutrient enrichment have been taken as, for instance, proposed in the European Water Framework Directive (EWFD; European Union, 2000). The EWFD requires that by 2015 all European water bodies must have a "good" ecological status. However, the answer to the key question, to what trophic level an aquatic system must be restored, remains often unsatisfactorily or even completely unanswered. Palaeolimnological studies can contribute to help solving this problem by defining pre-disturbance baseline and reference conditions and hence can have important implications for restoration programs (e.g., Bennion \& Battarbee, 2007). In this context, diatoms have been shown to be excellent indicators of trophic change and their siliceous frustules generally preserve well in sediments (e.g., Battarbee et al., 2001; Kirilova et al., 2009a; Smol, 2008). Moreover, diatoms are recognized by the EWFD as ecological indicator organisms for water quality changes. Since palaeolimnological studies can infer past environmental conditions (Smol, 2008), this line of research can provide valuable information about baseline conditions in lakes under natural and disturbed circumstances.

In European lowland regions such as the Netherlands, lakes have been thought to be exposed to increased nutrient enrichment, particularly since the 1950s, due to external input of nutrients (e.g., Gulati \& van Donk, 2002; Nienhuis et al., 2002; Bates et al., 2008) and this effect is amplified by climatic change. A recent palaeolimnological study showed eutrophic to hypertrophic conditions in a Dutch floodplain lake at least since the fifteenth century, caused primarily by human activities (Kirilova et al., 2009b). On a shorter time-scale Cremer et al. (2009a) showed that the artificially created Lake IJsselmeer, a former bay of the North Sea, has high phosphorus concentration since its formation in 1932. These examples indicate that at least some Dutch lakes featured high nutrient levels well before the peak period of eutrophication between the 1950s and 1970s as recorded in many other European countries such as Germany (e.g., Alefs \& Müller, 1999; Neumann et al., 2002), Switzerland (e.g., Lotter, 1998; Hausmann \& Kienast, 2006), Northern Ireland (e.g., Anderson et al., 1990; Gibson et al., 2003), Denmark (e.g., Rasmussen \& Anderson, 2005), or the UK (e.g., Bennion, 1994). The question still remains how widespread such elevated nutrient conditions were in the Netherlands before instrumental monitoring programs were implemented in the 1980s (Portielje \& van der Molen, 1998).

In this study, we aim at reconstructing the phosphorus history of eight Dutch lakes that have been created by human activity and were strongly modified. The intention is to provide representative records documenting the eutrophication history of typical moderately deep Dutch lakes during the past century. We also attempt to identify key factors that have been controlling the nutrient concentrations in these lakes. For this purpose, we analyzed well-dated fossil diatom assemblages preserved in the sediments and applied a diatom-based phosphorus inference model (transfer function) to study the time trajectories of total phosphorus concentrations.

\section{Study sites}

The eight studied lakes are located in the central part of the Netherlands (Fig. 1) in agricultural regions characterized by peaty and sandy soils. Lakes Maarsseveen, Plas Vechten, and Fort Vechten are in the vicinity of the town of Utrecht. Lakes Maarsseveen and Plas Vechten are both artificial lakes created in 1965 and 1941, respectively, by excavations of sand in a peat-bog area (Steenbergen \& Verdouw, 1982; van Donk, 1983). These lakes are currently mesotrophic, having no direct contact with agricultural land and are fed solely by groundwater and precipitation. The lake at Fort Vechten is a moat around a military fortress created in the eighteenth century. The unnamed lakes near the towns of Ammerzoden (unofficially named Lake Ammerzoden) and Empel (unofficially named Lakes Empel A and Empel B) as well as Haarsteegse Wiel (Fig. 1) were formed in the eighteenth century by dikebreaches of the river Meuse (Hudson et al., 2008). These lakes are located outside the polder and at high water stands in spring the lakes can be flooded. Moreover, the lakes are highly influenced by groundwater of riverine origin. Lake De Waay is located between the rivers Rhine and Linge and was created in 1496 as a consequence of a dike-breach (Kirilova et al., 2009b). All study lakes are dimictic. Major 


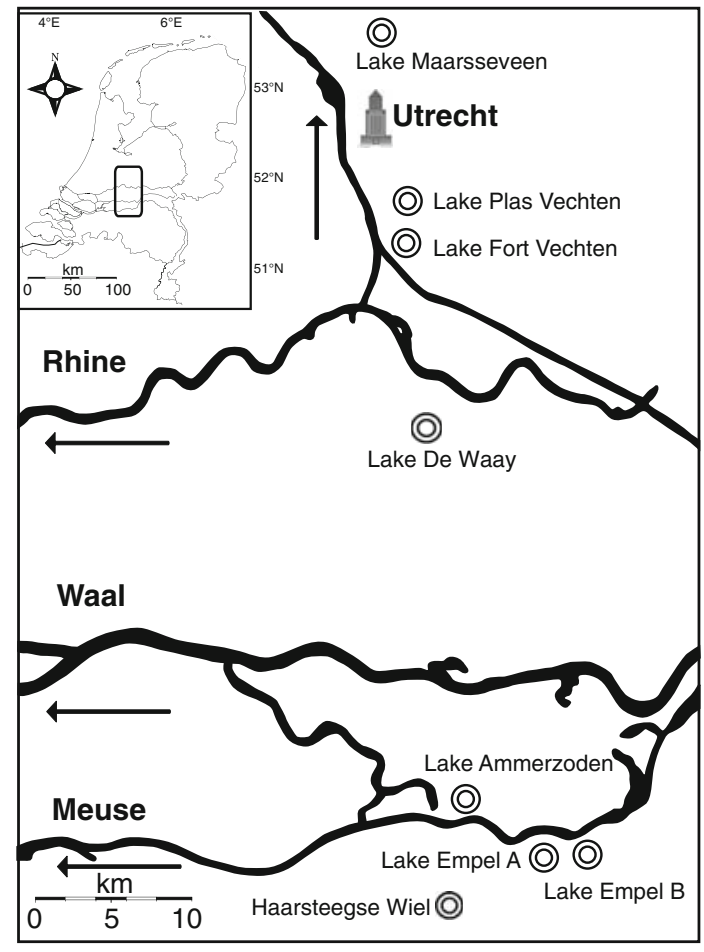

Fig. 1 Map of the Netherlands with the location of the studied lakes: Lake Ammerzoden, Lakes Empel A, Empel B, Plas Vechten, Maarsseveen, Fort Vechten, De Waay, and Haarsteegse Wiel

morphological and limnological characteristics of the lakes are documented in Table 1.

\section{Materials and methods}

All the lakes were sampled at the deepest part of the basin using an UWITEC gravity corer. The sediments of all eight lakes consist of organic-rich mud (gyttja). The sediments were sampled contiguously in $1 \mathrm{~cm}$ slices and the samples were subsequently freeze-dried. The chronologies for Lake Ammerzoden, Empel A, Fort Vechten, Plas Vechten, De Waay, and Haarsteegse Wiel are based on ${ }^{137} \mathrm{Cs}$ activity profiles measured at the Kernfysisch Versneller Instituut (KVI) at Groningen University (Rigollet \& de Meijer, 2002) and at the University of Waterloo Environmental Change Research Laboratory (Table 2).

For the diatom analysis, 94 sediment samples were processed with $\mathrm{H}_{2} \mathrm{O}_{2}(30 \%)$ and the suspensions were transferred to cover slips using the sedimentation tray method (Battarbee, 1973). The slides were mounted using Naphrax ${ }^{\circledR}$ and analyzed with an Olympus BX51 microscope at a magnification of $1,000 \times$. On each slide, between 300 and 500 diatom valves were counted. Diatoms were identified following Krammer \& Lange-Bertalot (1991, 1999a, b, 2000), Compère (2001), and Håkansson (2002).

The zonation of the diatom records was carried out using optimal sum of square partitioning (Birks \& Gordon, 1985) with the software ZONE (Lotter \& Juggins, 1991). The statistically significant number of zones was assessed by applying the broken stick model (Bennett, 1996).

Diatom-inferred total phosphorus (DI-TP) reconstructions were performed using a training set from the European Diatom Database Initiative (EDDI, http://craticula.ncl.ac.uk/Eddi/jsp/) consisting of 347 lakes. DI-TP values were calculated using weighted averaging partial least squares (WA-PLS) regression and calibration (ter Braak et al., 1993; ter Braak and Juggins, 1993) as implemented in the software C2 (version 1.5, Juggins, 2007). The percentage diatom data were square-root and the TP values were log transformed. The inference model performance was assessed using leave-one-out cross-validation. The transfer function has a bootstrapped $r^{2}$ of 0.75 and a root mean square error of prediction (RMSEP) of $1.86 \log$ TP units. A detrended correspondence analysis (DCA) using the software CANOCO 4.5 (ter Braak \& Šmilauer, 2002) was performed to explore the relationships between diatom assemblages of all studied samples with respect to their diatom composition. A gradient length of the first axis of $2.8 \mathrm{SD}$ units indicated that the dataset was well suited for applying unimodal response models (ter Braak \& Prentice, 1988; Birks, 1997). The percentage data were square-root transformed and rare taxa were down weighted.

\section{Results}

\section{Chronology (Fig. 2)}

The ${ }^{137}$ Cs activity profiles of Lakes Ammerzoden, Empel A, Fort Vechten, Plas Vechten, De Waay, and Haarsteegse Wiel (Fig. 2; Table 2) show the two distinct ${ }^{137} \mathrm{Cs}$ excursions that are commonly found in European lake sediments (Appleby, 2001): the activity 
Table 1 Main physico-chemical characteristics of Lakes Ammerzoden, Empel A, Empel B, Maarsseveen, De Waay, and Fort Vechten (data measured on January 13 2006); Plas
Vechten (data from Hordijk, 1993; Gulati \& Parma, 1982); Lake Haarsteegse Wiel (Cremer et al., 2009a)

\begin{tabular}{|c|c|c|c|c|c|c|c|c|}
\hline & Ammerzoden & Empel A & Empel B & $\begin{array}{l}\text { De } \\
\text { Waay }\end{array}$ & $\begin{array}{l}\text { Haarsteegse } \\
\text { Wiel }\end{array}$ & $\begin{array}{l}\text { Plas } \\
\text { Vechten }\end{array}$ & $\begin{array}{l}\text { Fort } \\
\text { Vechten }\end{array}$ & Maarsseveen \\
\hline Maximum depth (m) & 4.4 & 3.9 & 10.2 & 15 & 17 & 11.9 & 4.0 & 32.0 \\
\hline Surface area (ha) & 1.65 & 0.75 & 1.06 & 1.3 & 17.9 & 4.7 & 8.1 & 70 \\
\hline Conductivity $\left(\mu \mathrm{S} \mathrm{cm}{ }^{-1}\right)$ & 367 & 446 & 370 & 620 & - & - & 499 & 464 \\
\hline Alkalinity $\left(\mathrm{mEq} 1^{-1}\right)$ & 2.1 & 2.0 & 1.6 & 2.8 & - & - & 3.4 & 2.6 \\
\hline $\mathrm{pH}$ & 8.4 & 7.9 & 7.9 & 8.2 & - & 8.3 & 7.7 & 8.0 \\
\hline
\end{tabular}

Table 2 Sedimentation rates based on ${ }^{137}$ Cs-dated sediment cores from Lakes Ammerzoden, Empel A, Plas Vechten, De Waay, Haatsteegse Wiel, and Fort Vechten

\begin{tabular}{|c|c|c|c|c|c|c|}
\hline Lake & Ammerzoden & Empel A & De Waay & $\begin{array}{l}\text { Haarsteegse } \\
\text { Wiel }\end{array}$ & $\begin{array}{l}\text { Fort } \\
\text { Vechten }\end{array}$ & $\begin{array}{l}\text { Plas } \\
\text { Vechten }\end{array}$ \\
\hline Core length $[\mathrm{cm}]$ & 100 & 70 & 156 & 68 & 45 & 45 \\
\hline Chernobyl event 1986 [cm depth in core] & 48 & 34 & 20.5 & 21 & 22 & 10 \\
\hline 1963 bomb tests [cm depth in cores] & 80 & 50 & 38.5 & 34 & 62.5 & 32 \\
\hline Sedimentation rate $1986-2006\left[\mathrm{~cm}_{\text {year }}{ }^{-1}\right]$ & 2.6 & 1.7 & - & 0.95 & - & - \\
\hline Sedimentation rate $1986-2002\left[\mathrm{~cm}\right.$ year $\left.^{-1}\right]$ & - & - & - & - & 1.8 & 0.75 \\
\hline Sedimentation rate $1986-2005\left[\mathrm{~cm}\right.$ year $\left.^{-1}\right]$ & - & - & 1.08 & - & - & - \\
\hline Sedimentation rate $1963-1986\left[\mathrm{~cm}\right.$ year $\left.^{-1}\right]$ & 1.3 & 0.7 & 0.8 & 0.6 & 1.5 & 0.84 \\
\hline
\end{tabular}

Fig. 2 Measured activities of ${ }^{137} \mathrm{Cs}$ (with standard deviations) in sediment cores from Lake Ammerzoden, Lake Empel A, Lake De Waay, Haarsteegse Wiel, Lake Fort Vechten, and Lake Plas Vechten

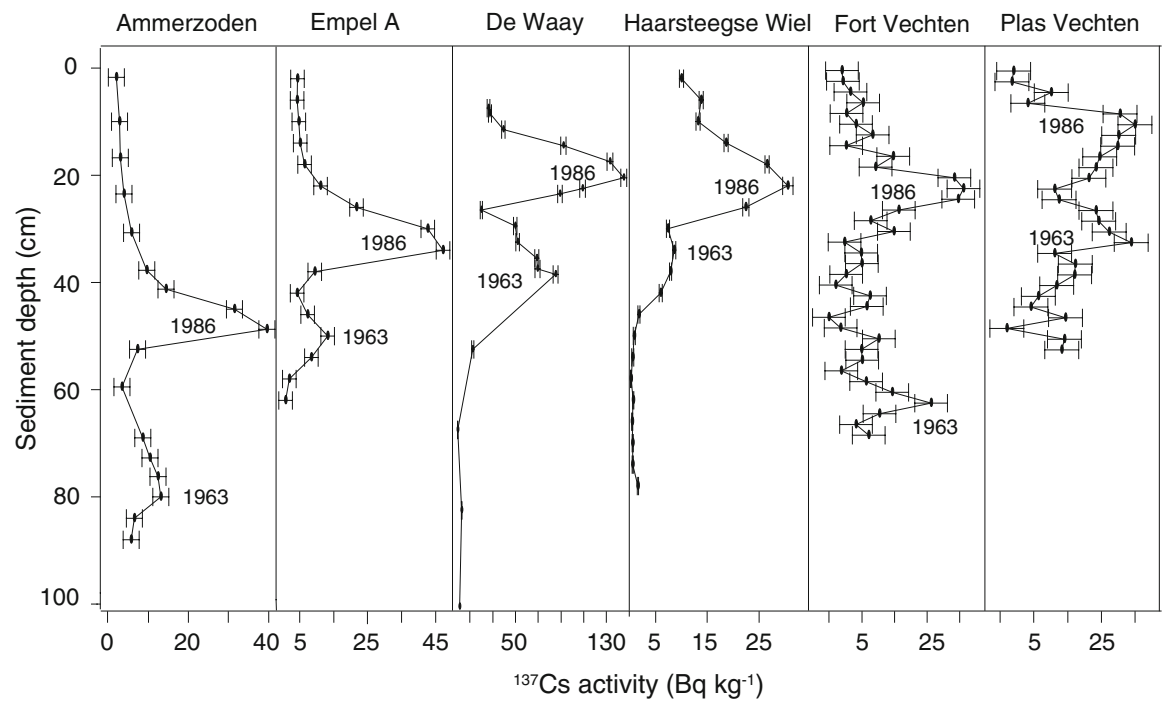

peak resulting from the Chernobyl reactor accident in 1986 and the elevated caesium activity in 1963 as a result of various atmospheric atomic bomb tests carried out in the early 1960 s.

The chronology for Lake Empel B was established by correlation with Lake Empel A located at a distance of $600 \mathrm{~m}$, assuming comparable sedimentation rates. The organic part of the sediment core of Lake Maarsseveen is $17 \mathrm{~cm}$ long before reaching the basal sand layer. Taking into account that the lake was created in 1965, its sedimentation rate and chronology are based on a linear interpolation between the top 
(year of sampling, 2005) and bottom of the core (year of lake origin, 1965).

Diatom assemblages and phosphorus reconstruction (Figs. 3a-c, 5)

\section{Lake Ammerzoden}

The diatom record of this lake can be subdivided into three zones. In zone A1, reflecting the period between the mid-1940s and the 1970s, the most abundant diatoms include Cyclostephanos invisitatus, Asterionella formosa, and Aulacoseira ambigua. During this period, the DI-TP concentration was $80-150 \mu \mathrm{g}^{-1}$, whereas between the mid-1960s and the early 1980s it increased slightly toward values of $\sim 140 \mu \mathrm{g} \mathrm{l}^{-1}$. The most abundant diatom of zone A2, representing the period between the 1970s and the 1990s, is Cyclostephanos dubius ( 40\%). This species, together with Stephanodiscus hantzschii, is also the most abundant diatom of zone A3 that represents the youngest history of the lake: during the 1990s, the DI-TP concentration reached values $>200 \mu \mathrm{g}^{-1}$ before they decreased in the late 1990s to about $130 \mu \mathrm{g}^{-1}$.

\section{Lake Empel A}

During zone EA1 that covers the period of the 1930s to the 1960s A. ambigua, A. granulata, and C. dubius showed high relative abundances, and from the beginning of this period to the early 1940s DI-TP was between 80 and $100 \mu \mathrm{g} \mathrm{l^{-1 }}$. S. hantzschii and Cyclotella meneghiniana were the dominant taxa during zone EA2 (1960s to early-1980s), whereas during EA3 (early-1980s to 2006) C. dubius became again the most abundant diatom. Between the mid1940s and the mid-1990s, the DI-TP concentrations were 200-300 $\mu \mathrm{g}^{-1}$. Since ca. 2000, the DI-TP concentrations decreased to about $\sim 100 \mu \mathrm{g}^{-1}$.

\section{Lake Empel B}

In zone EB1 (1930s to early 1980s), Stephanodiscus parvus, S. hantzschii, C. dubius, and Aulacoseira subarctica were the main diatoms, whereas in zone EB2 (mid-1980 s to 2006) the assemblages were dominated by $S$. parvus (60\%). The DI-TP values point to two main periods. From the 1930s to the late 1950s, the DI-TP was $\sim 100 \mu \mathrm{g} \mathrm{l}^{-1}$, whereas it decreased to $\sim 80 \mu \mathrm{g} \mathrm{l}^{-1}$ since then.

\section{Lake De Waay}

In the first zone W1 (1920s to early 1960s), the diatoms with high percentages were $S$. hantzschii, Puncticulata bodanica, $P$. radiosa, and $S$. medius. $S$. hantzschii was the dominant diatom in zone W2 (1960s to 2005), but A. formosa and A. granulata showed high abundances as well. The average DI-TP concentrations for the period between the 1910s and the mid-1950s were around $40 \mu \mathrm{g} \mathrm{l}^{-1}$ before they increased steadily up to $80 \mu \mathrm{g}^{-1}$ since the mid-1950s.

\section{Lake Haarsteegse Wiel}

In zone H1 (late 1890s to late 1930s), Puncticulata radiosa was the main diatom species. From the late 1930s to the 1970s (H2), the dominant diatoms were $S$. parvus followed by $P$. radiosa and $S$. medius. In zone H3 (1970s to 2006), S. parvus, P. radiosa, $S$. medius, $F$. crotonensis, Cyclotella ocellata, and A. granulata occurred in high percentages. Since the end of the nineteenth century to today, the DI-TP values were more or less stable between 40 and $60 \mu \mathrm{g} 1^{-1}$.

\section{Lake Fort Vechten}

In zone FV1 (early 1970s to mid-1980s), C. dubius and $A$. granulata were the major diatoms with $P$. bodanica, $P$. radiosa, and $C$. kuetzingiana also playing an important role. The DI-TP ranged between 40 and $90 \mu \mathrm{g}^{-1}$. The percentages of $P$. bodanica, $P$. radiosa, and $C$. kuetzingiana decreased during zone FV2 (late 1980s to 2002), while C. dubius, A. granulata, and $S$. parvus became more abundant. DI-TP values varied between 35 and $45 \mu \mathrm{g}^{-1}$ during the period 1980-1990, while they increased to $80-90 \mu \mathrm{g}^{-1}$ since 1990 .

\section{Lake Maarsseveen}

From the creation of the lake in 1965, until the late 1980s (zone MV1) A. subarctica reached about $60 \%$ of the diatom total. During zone MV2 (1990s to 2005), A. subarctica was replaced by Cyclotella cyclopuncta. The lake exhibits stable conditions of $\sim 10 \mu \mathrm{g}^{-1}$ DI-TP throughout its whole history. 
Fig. 3 a, b, c Diatom stratigraphies of the eight studied lakes showing only the most abundant diatoms. Values are given as percentages of total diatoms
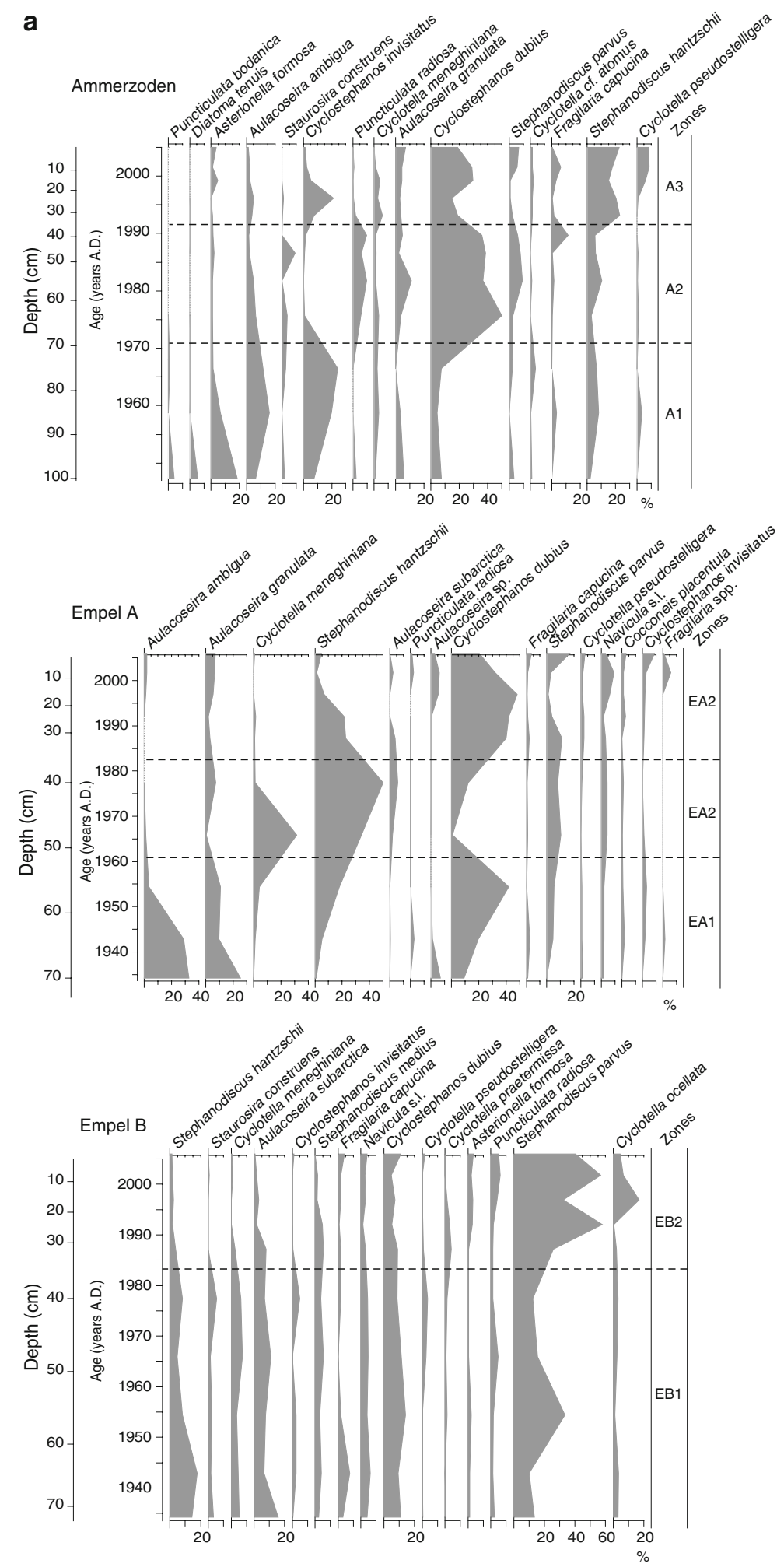
Fig. 3 continued

\section{Lake Plas Vechten}

Puncticulata bodanica and Stephanodiscus medius represent with between 40 and $60 \%$ of the diatom assemblages during zone PV1 (1950s to mid-1980s), DI-TP concentrations were on average $\sim 7 \mu \mathrm{g} \mathrm{l}^{-1}$. In zone PV2 (mid-1980s to 2006), the diatom assemblages were dominated by $S$. medius, $S$. parvus, $A$. formosa, Cyclotella kuetzingiana, Diatoma tenuis,

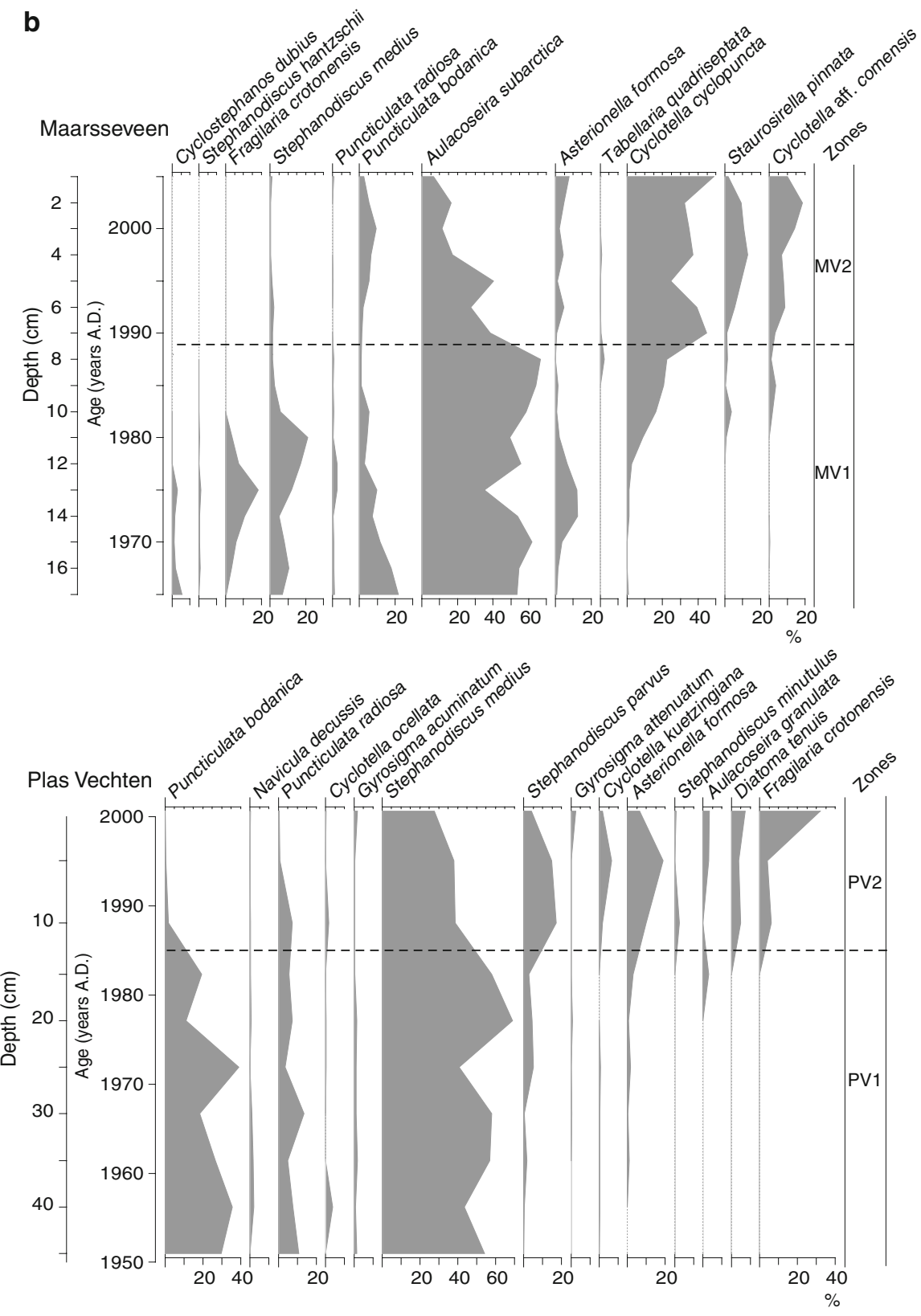

and Fragilaria crotonensis. DI-TP concentrations increased to about $30 \mu \mathrm{g}^{-1}$ in the past 20 years.

DCA analysis (Fig. 4)

The diatom assemblages of each individual lake show a unique development through time. All of the lakes (except De Waay) exhibit a change in the diatom assemblages over time. Lake De Waay represents an 
Fig. 3 continued
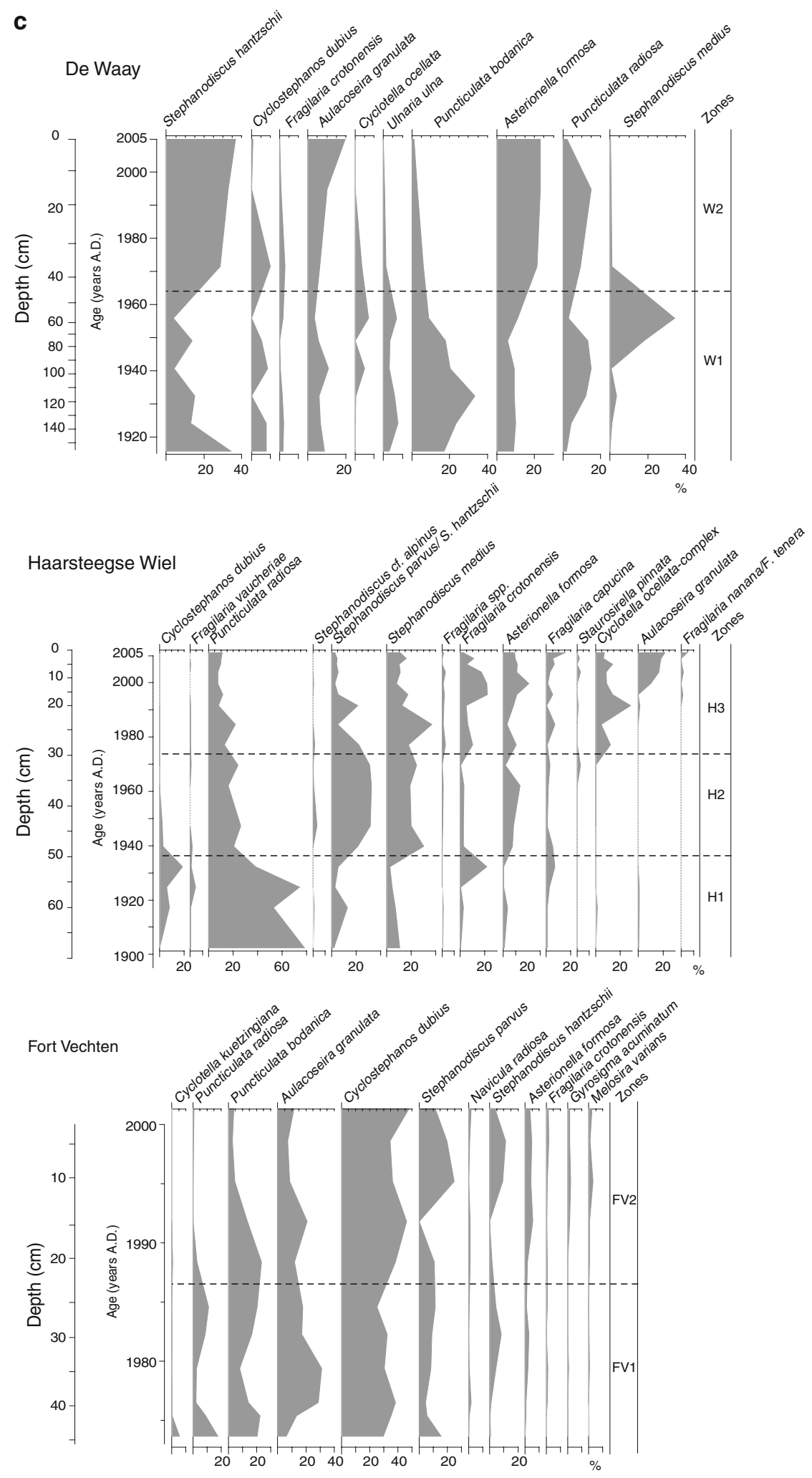
Fig. 4 Detrended Correspondence Analysis (DCA) of 94 subfossil diatom samples from the eight studied Dutch lakes. Axes are in standard deviation units. The abbreviations of the lakes are as follows: $M V$ Maarsseveen, $P V$ Plas Vechten, WAY De Waay, $F V$ Fort Vechten, WAM Lake Ammerzoden, WEA Lakes Empel A, WEB Empel B, and $H A$ Haarsteegse Wiel

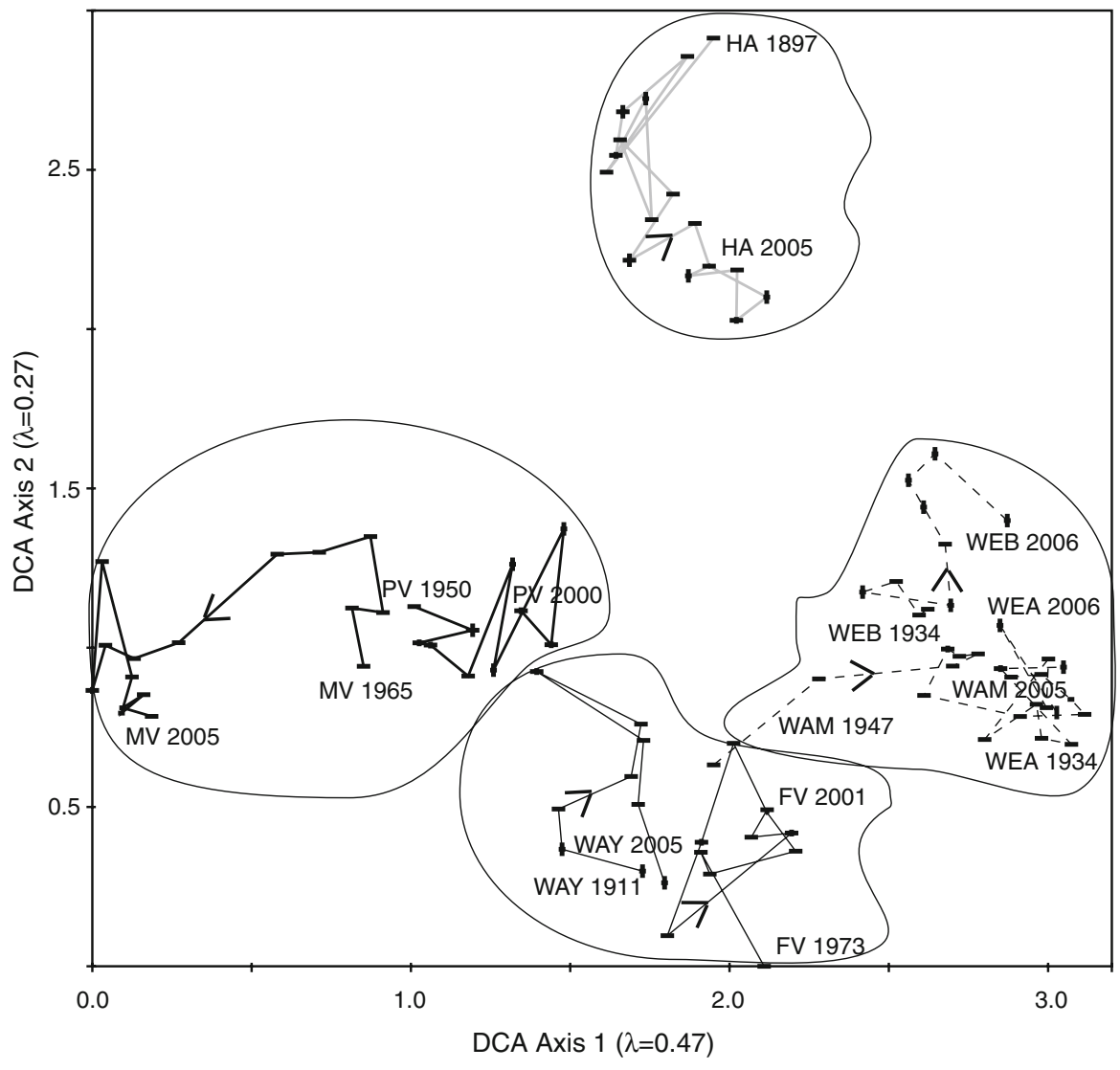

exception: despite a shift in the time trajectory, the top and the bottom assemblages are very similar.

It is apparent that the DCA (Fig. 4) indicates a subdivision of the diatom assemblages of the different lakes on the first and second axes into four groups: (i) Lake Maarsseveen and Lake Plas Vechten; (ii) Lake Fort Vechten and Lake De Waay; (iii) Lakes Ammerzoden, Empel A, and Empel B; and (iv) Haaersteegse Wiel as a group apart.

\section{Discussion}

The fossil records ranged from covering the past three decades to encompassing the past century and provided the opportunity to assess whether an increase in nutrient enrichment had indeed happened since the 1950s.

A range of different diatom species such as Aulacoseira granulata, A. subarctica, C. dubius, C. invisitatus, C. meneghiniana, C. ocellata, C. cyclopuncta, P. bodanica, S. hantzschii, S. medius, and S. parvus dominated the studied lakes during the past century. Most of these diatoms are typically found in meso- to eutrophic lakes (e.g., van Dam et al., 1994). The first DCA axis (Fig. 4) is reflecting the trophic state, as indicated by the separation of lakes with low nutrient levels (Lakes Maarsseveen and Plas Vechten) from those with higher nutrient levels (Lake De Waay, Lake Fort Vechten, Lakes Ammerzoden, Empel A, and Empel B). Although the lakes show a grouping along the trophic gradient, their individual time trajectories are complex, especially for the eutrophic and hypertrophic lakes (Fig. 4). This complex history of each lake is reflected by the individualistic reaction of their diatom assemblages independent of the similar management or catchment history.

The dike-breach lakes (Lake Ammerzoden, Empel A, and Empel B) have a very similar diatom composition and are showing clear anthropogenically induced eutrophication (e.g., Anderson, 1997). Through most of the studied time interval the diatom assemblages were dominated by C. dubius, S. parvus, and $S$. hantzschii, which are diatoms typical for 
eutrophic and hypertrophic lakes (e.g., van Dam et al., 1994). These three species alternated in dominance, especially between the late 1960s and the 1980s (Fig. 3a). During the late 1960s and the 1980s, the use of fertilizers rapidly increased in the Netherlands (e.g., Wolf et al., 2003), which resulted also in changes in the composition of diatom assemblages and alternation in dominant species all typical for eutrophic waters (e.g., Ramstack et al., 2003; Bradbury et al., 2004).

After the late 1980s, TP concentrations in many lakes in the Netherlands decreased, which reflects the result of water protection and restoration measures (Portielje \& van der Molen, 1998). Moreover, measures such as phosphate removal from wastewaters and detergents, together with the reduction of phosphorus in agriculture led also to a substantial decrease in the nutrient enrichment of surface waters (see e.g., van der Molen \& Boers, 1999 and references therein; Cremer et al., 2009b).

Despite the nutrient reduction, all of the dikebreach lakes remained eutrophic. When determining the ecological development of dike-breach lakes, we have to keep in mind that they are highly dependent on flooding frequency and river groundwater supply, and that the catchment of these lakes often consists of cultivated areas (Kirilova et al., 2009b; Hudson et al., 2008). The three dike-breach lakes examined in this study (Ammerzoden, Empel A, and Emel B) are located within the delta flood-plain of the River Meuse. Floodplain rivers are commonly characterized by naturally high nutrient concentrations (e.g., Vannote et al., 1980) and the River Meuse has been strongly affected by cultural eutrophication. The quality of the River Meuse water deteriorated to reach maximum nutrient concentrations in the 1970 s and its nutrient level is still higher than the natural background concentrations (van Vliet \& Zwolsman, 2008). This high nutrient loading of the river may also influence the nutrient concentrations in the regional groundwater and contributes to the high TP concentrations observed in floodplain lakes (Shaw et al., 1990; Holman et al., 2008). As a result, the DI-TP concentrations in the dike-breach lakes were between $\sim 70$ and $300 \mu \mathrm{g}^{-1}$ during the past 50 years.

The dike-breach Lake De Waay does not group with the other dike-breach lakes as could be expected (Fig. 4). A study of Lake De Waay (created in the fifteenth century) has shown that this lake's trophic history was strongly influenced by repeated flooding events, runoff from surrounding agricultural land, and sewage input into the lake from a neighboring town. Between fifteenth and eighteenth century, the background DI-TP concentrations were around $300 \mu \mathrm{g} \mathrm{l}^{-1}$. However, since the beginning of the twentieth century the direct nutrient sources, which were connected to the lake and the river floods were not affecting the lake anymore (Kirilova et al., 2009b). Consequently, our reconstructions show mesotrophic conditions and DI-TP of $40 \mu \mathrm{g} \mathrm{l}^{-1}$ since the mid-twentieth century. After the 1950s, a reeutrophication phase took place due to the increased agricultural activity in the vicinity of the lake.

The diatom assemblages from Haarsteegse Wiel also form a separate group (Fig. 3b). The diatom assemblages from this lake indicate stable meso- to eutrophic conditions throughout the past century until today. The reconstruction of the trophic history of this lake indicates DI-TP of $40 \mu \mathrm{g} \mathrm{l}^{-1}$ from the beginning of its creation by a dike-breach in 1740 . The lake was protected by strong dike constructions and only five floods have affected the lake (Cremer et al., 2009b). The slight DI-TP increase after the 1970s was explained by the change of the agricultural practices in the lake catchment (Cremer et al., 2009b).

The separation of the dike-breach Lakes De Waay and Haarsteegse Wiel on the second DCA axis (Fig. 4) suggests that the strong catchment management defines their nutrient status nowadays. These lakes are not affected by river floods anymore due to their location inside the polder, in contrast to the rest of the dikebreach lakes that are located on the river floodplain.

The palaeolimnology of castle moats has rarely been studied and the few published observations show that the limnology of moats is highly dependent on human activities (e.g., Beneš et al., 2002). The lake at Fort Vechten shows eutrophic to hypertrophic conditions during its youngest history (Fig. 5) with a slight decline in trophic state between the late 1980s and the early 1990s. The moat is located in a cultivated area. It is connected to various ditches and canals that transport water from the agricultural land which is likely responsible for the overall high DI-TP concentrations of $150 \mu \mathrm{g} \mathrm{l}^{-1}$ (Fig. 5). The grouping of the moat and the dike-breach Lake De Waay (Fig. 4), completely different types of lakes according to their origin and development, indicates the overprinting human influence on the nutrient input into these lakes. Without the fundamental regulation 


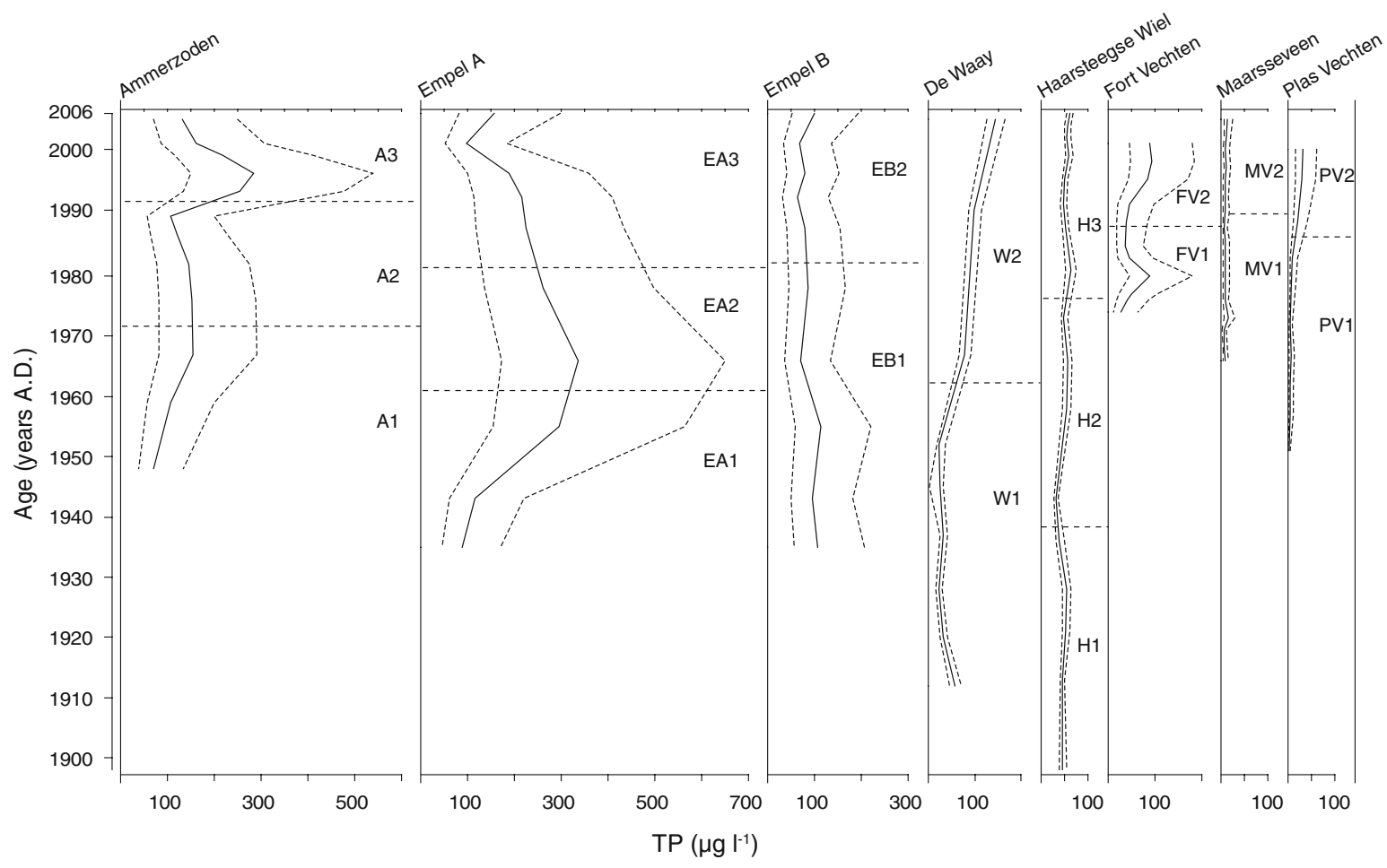

Fig. 5 Diatom-inferred TP (DI-TP) concentrations of the eight studied lakes. Dotted lines represent the sample specific standard error of prediction. The zones are the same as in Fig. 3

of the rivers at the end of the nineteenth century (Gottschalk, 1975, 1977), Lake De Waay would have kept its high TP concentrations as is observed in the other three dike-breach lakes (Fig. 5) that can still be influenced by seasonal flooding and riverine ground water input.

Lakes Maarsseveen and Plas Vechten are artificial lakes with low nutrient concentrations. The low DITP concentrations for both lakes (Fig. 5) reflect the fact that these lakes are mainly fed by precipitation and by nutrient-poor groundwater (Hordijk, 1993; Steenbergen \& Verdouw, 1982; van Donk, 1983) and are not influenced by river activity.

Lake Plas Vechten is an isolated seepage lake with neither an outlet nor an inlet. However, the groundwater discharge into the lake is mainly horizontal and nutrient rich, which is likely a consequence of the agricultural activities in the region (Steenbergen \& Verdouw, 1982). Vertical groundwater discharge is negligible since the lake bottom is artificially sealed with a clay layer that impedes vertical water movement. The hydrological setup of the lake isolates it from contact with groundwater nutrient sources and no known local point sources are present. According to Blaauboer (1982), the nutrient concentrations in Lake Plas Vechten were increasing between 1956 and 1979, with the effect of a distinct shift in the phytoplankton communities. These results are in agreement with our reconstruction showing that from 1950s until 1980s the abundance of $P$. bodanica was decreasing thus indicating a shift in the trophic state, from meso- to eutrophic conditions (van Dam et al., 1994). At the end of the 1970s, the relative abundance of diatoms such as $S$. parvus and $S$. minutulus increased, indicating hypertrophic nutrient levels (van Dam et al., 1994). Best (1982) described a decline in macrophytes in Lake Plas Vechten in the period of 1963 to 1980 and also showed that in the summer periods from 1978 onwards the lake's catchment was used as farm land, fertilized by artificial fertilizer and cattle manure. Steenbergen and Verdouw (1982) concluded that phosphorus release from the sediments and turbulent eddy flows play a significant role for the transport of nutrients from the hypo- to the epilimnion in this lake. After 1980, when nutrient input increased and consequently 
led to enhanced primary production, this may have played a significant role in accelerating eutrophication in Lake Plas Vechten.

In comparison with Lake Plas Vechten, stable oligoto mesotrophic conditions are characterizing Lake Maarsseveen throughout its history. In contrast to Lake Plas Vechten, Lake Maarsseveen is fed by precipitation and groundwater that is filtered through Pleistocene sandy deposits, thus leading to low nutrient concentrations (van Donk, 1987). The diatom composition clearly indicates low TP concentrations in Lake Maarsseveen (DI-TP $10-14 \mu \mathrm{g} \mathrm{l}^{-1}$ ). After the mid1980s, A. subarctica was outcompeted by C. cyclopuncta, suggesting a slight decline in TP concentrations, which is also reflected in the DI-TP reconstruction (Figs. 3, 5). Furthermore, after the mid-1980s the relative abundance of diatoms indicative of eutrophic conditions such as S. hantzschii, $C$. dubius, and S. medius (van Dam et al., 1994) decreased considerably. These diatoms previously occurred in very low abundances and are spring bloomers. They are likely to appear in oligotrophic lakes during the period of spring overturn when nutrients are mixed into the water column (Hickel \& Håkansson, 1993). Since this is an artificial lake it is conceivable that the shift in nutrients between the mid-1960s and the mid-1980s is a succession from a state with abundant available nutrients after excavation and formation of the lake to a more stable ecosystem with lower nutrient concentrations (e.g., Moss, 1998). Agricultural activity in the region decreased after the 1980s (Portielje \& van der Molen, 1998). However, Lake Maarsseveen has never been directly influenced by farming activities (van Donk, personal communication). This lake is a deep lake (Table 1) making it more resistant to the effects of recreational activities. In contrast, shallow lakes are more susceptible to various anthropogenic activities that may trigger algal blooms and a subsequent increase in turbidity. Together with sediment resuspension this can lead to accelerated eutrophication (Scheffer, 2004). Hence, Lake Maarsseveen is more resilient to disturbance and was, therefore, able to remain in its oligotrophic state.

Lake water quality and effectiveness of restoration programs

According to the Dutch standards all studied lakes (except the moat Fort Vechten -M 16) belong to the same lake type-M 20 (medium size deep buffered lakes) (Stowa, 2008). However, a comparison of the eight DI-TP records (Fig. 5) shows different eutrophication histories and individualistic reactions of the studied lakes with regard to catchment processes. In many modern studies, it has been underlined that despite the decrease in nutrient input, lake ecosystems did not return to their original trophic state which is mostly thought to be oligotrophic. As the theory "Return to Neverland" (Duarte et al., 2008) emphasizes, the trajectories of lakes may be irreversible so that the lakes are moving away from their reference conditions even under reduced nutrient input. Moreover, the present palaeolimnological study allows an assessment of the effectiveness of the water quality restoration programs. We underline how the absence and underestimation of background information on both the lake origin and the history can be misleading in taking management decisions and may, based on general expectations, lead to unsatisfactory results. Given the overprinting human impact on these floodplain lakes it is unlikely that these ecosystems can reach a low trophic state. In such, heavily anthropogenically influenced ecosystems in particular, the good ecological status theory should reflect the fact that lowland lakes are prone to eutrophication and, in many cases, not able to reach sustainable low TP values. A returning to baseline conditions as shown in other studies (e.g., Kirilova et al., 2009a; Kirilova et al., 2009b) is unrealistic for this region. For instance, some lakes such as Lakes Fort Vechten, De Waay, and Plas Vechten are characterized by increasing DI-TP values during the past 20-50 years, despite the measures undertaken to reduce nutrient input. Similarly, diatom assemblages in Lake Ammerzoden indicate a distinct increase in DI-TP around 1990, although the lake reverted to lower DI-TP a decade later. However, under strong lake management, Lakes Maarsseveen and Haarsteegse show only minor changes in DI-TP and the diatom assemblages show very similar trophic states for the time-intervals covered in our study. Lake Empel A finally shows the highest DI-TP between the 1950s and the 1960s with a decrease in trophic state thereafter, but being still in eutrophic state. Our results indicate that the different lake ecosystems responded individualistically to changing external TP sources and internal TP feedback mechanisms. In the context of our study, both the origin of the lakes and 
the local development of nutrient sources are more important for determining their trophic history than mechanisms working at the regional scale.

\section{Conclusions}

Overall, most of the lakes in our study showed only relatively small changes in their nutrient content during their youngest history. Their trophic state was regulated mostly by the way they are fed (groundwater and seepage) and managed (flood control). Our results allow a distinction of four main lake types. The dike-breach lakes (Ammerzoden, Empel A, and Empel B) are strongly affected by flood regulation and riverine groundwater supply. Taking into account the DI-TP of 100-300 $\mu \mathrm{g}^{-1}$ reconstructed for these lakes throughout the past century it is apparent that not solely agriculture was responsible for the high TP concentrations but also nutrient-enriched riverine groundwater played an important role. The artificial Lakes Maarsseveen and Plas Vechten, which are both mainly fed by seepage and groundwater, have been in oligo- to mesotrophic conditions throughout their history indicating that their nutrient budgets were not strongly affected by humans. Lakes Fort Vechten and De Waay, being a moat around a fortress and a dikebreach lake, respectively, exhibit eutrophic to hypertrophic conditions and an individualistic behavior, suggesting that their trophic state is strongly regulated by anthropogenic action in their watershed. Lake Haarsteegse Wiel displays stable meso- to eutrophic conditions for the past century indicating the importance of lake management since the creation of this dike-breach lake and the strong agricultural influence on the lake's TP concentrations.

Both the origin and the main water sources of the investigated Dutch lakes should be taken into account for adequately setting up restoration programs, especially in regions with lakes of different origins such as the Netherlands. Each lake displays distinct diatom assemblages as evidenced by the DCA (Fig. 4), underlining the individualistic time trajectories with regard to changes in trophic state. However, the composition of diatom assemblages is not only controlled by nutrient variability but also by factors such as water depth, interspecific competition, and/or macrophyte development.
With the exception of two lakes (Plas Vechten and De Waay), we observed no major increasing trends in DI-TP concentrations. For Lakes Maarsseveen and Plas Vechten, the sediment cores reached back to the time of their formation in 1965 and 1951, respectively. For the other lakes, our results indicate that if they have experienced major phases of eutrophication these would be recorded in older sediment sections that have not been sampled by our short cores. Furthermore, we show that within the relatively small region we examined the four groups of lakes exhibit an individual pattern in their development and have unique trophic histories. This implies that whether reference conditions or restoration targets are defined, as, e.g., the EWFD demands, these will have to be assessed separately for different lake types even if they are located within a rather homogeneous geographical or climatological region. In addition, our results highlight the need for palaeolimnogical studies that document the long-term development of aquatic ecosystems and thus allow assessing background nutrient levels and ecological conditions for individual lake systems for the period preceding detailed limnological monitoring programs.

Acknowledgments We would like to thank Ton van Druten and Roland Hall for their help with collecting the sediment cores. TNO Environment and Geosciences is acknowledged for providing the ${ }^{137} \mathrm{Cs}$ dating of the sediments from Lakes Ammerzoden, Empel A, Plas Vechten, and Fort Vechten. Johan Wiklund performed radiometric dating for Lake De Waay using gamma spectroscopy. Two anonymous reviewers are thanked for their constructive criticism. Special thanks go to Adam Ehrat for his linguistic comments on the article. This is Netherlands Research School of Sedimentary Geology (NSG) contribution no. 20091102.

Open Access This article is distributed under the terms of the Creative Commons Attribution Noncommercial License which permits any noncommercial use, distribution, and reproduction in any medium, provided the original author(s) and source are credited.

\section{References}

Alefs, J. \& J. Müller, 1999. Differences in the eutrophication dynamics of Ammersee and Starnberger See (Southern Germany), reflected by the diatom succession in varved sediments. Journal of Paleolimnology 21: 395-407.

Anderson, N. J., 1997. Historical changes in epilimnetic phosphorus concentrations in six rural lakes in Northern Ireland. Freshwater Biology 38: 427-440. 
Anderson, N. J., B. Rippey \& A. C. Stevenson, 1990. Change to a diatom assemblage in a eutrophic lake following point source nutrient re-direction: a palaeolimnological approach. Freshwater Biology 23: 205-217.

Appleby, P. G., 2001. Chronostratigraphic techniques in recent sediments. In Last, W. M. \& J. P. Smol (eds), Tracking Environmental Change Using Lake Sediments. Kluwer Academic Publishers, Dordrecht: 171-203.

Bates, B. C., Z. W. Kundzewicz, S. Wu \& J. P. Palutikof (eds), 2008. Climate Change and Water. Technical Paper of the Intergovernmental Panel on Climate Change, IPCC Secretariat, Geneva, $210 \mathrm{pp}$.

Battarbee, R. W., 1973. A new method for estimation of absolute microfossil numbers, with reference especially to diatoms. Limnology and Oceanography 18: 647-653.

Battarbee, R. W., V. J. Jones, R. J. Flower, N. J. Cameron, H. Bennion, L. Carvalho \& S. Juggins, 2001. Diatoms as indicators of surface water acidity. In Smol, J. P., H. J. B. Birks \& W. M. Last (eds), Tracking Environmental Changes Using Lake Sediments: Terrestrial, Algal, and Siliceous Indicators, Vol. 3. Kluwer Academic Publishers, The Netherlands: 155-203.

Beneš, J., J. Kaštovsky, R. Kočárová, P. Kočár, K. Kubečková, P. Pokorný \& P. Starec, 2002. Archaeobotany of the old Prague Town defense system, Czech Republic: archaeology, macroremains, pollen, and diatoms. Vegetation History and Archaeobotany 11: 107-111.

Bennett, K. D., 1996. Determination of the number of zones in a biostratigraphical sequence. New Phytology 132: 155-170.

Bennion, H., 1994. A diatom-phosphorus transfer function for shallow, eutrophic ponds in southeast England. Hydrobiologia 275(276): 391-410.

Bennion, H. \& R. W. Battarbee, 2007. The European Union Water Framework Directive: opportunities for palaeolimnology. Journal of Paleolimnology 38: 285-295.

Best, E. P. H., 1982. The aquatic macrophytes of Lake Vechten. Species composition, spatial distribution and production. In Gulati, R. D. \& S. Parma (eds), Developments in Hydrology 11, Studies on Lake Vechten and Tjeuemeer, The Netherlands. DR W. Junk Publisher, The Hague: 383.

Birks, H. H., 1997. A reconstruction of the aquatic ecosystem development in Kråkenes Lake, Norway, during the lateglacial and early Holocene. Würzburger Geographische Manuskripte 41: 31-32.

Birks, H. J. B. \& A. D. Gordon, 1985. Numerical Methods in Quaternary Pollen Analysis. Academic Press, London.

Blaauboer, M. C. I., 1982. The phytoplankton species composition and the seasonal periodicity in Lake Vechten from 1956 to 1979. In Gulati, R. D. \& S. Parma (eds), Developments in Hydrology 11, Studies on Lake Vechten and Tjeukemeer, The Netherlands. DR W. Junk Publisher, The Hague: 383.

Bradbury, P. J., S. M. Colman \& R. L. Reynolds, 2004. The history of recent limnological changes and human impact on Upper Klamath Lake, Oregon. Journal of Paleolimnology 31: 151-165.

Carpenter, S. R., D. Ludwig \& W. A. Brock, 1999. Management of eutrophication for lakes subject to potentially irreversible change. Ecological Applications 9: 751-771.

Compère, P., 2001. Ulnaria (Kützing) Compère, a new genus name for Fragilaria subgen. Alterasynedra Lange-Bertalot with comments on the typifiction of Synedra Ehrenberg. In Jahn, R., J. P. Kociolek, A. Witkowski \& P. Compère (eds), Studies on Diatoms. Ganter, Ruggell: 64-97.

Cremer, H., F. P. M. Bunnik, E. P. Kirilova, E. H. R. R. Lammens \& A. F. Lotter, 2009a. Diatom-inferred trophic history of IJsselmeer (The Netherlands). Hydrobiologia. doi 10.1007/s10750-009-9816-7.

Cremer, H., F. Bunnik, T. Donders \& H. Koolmees, 2009b. Kiezelalgen documenteren historische waterkwaliteit van diepe meren. $\mathrm{H}_{2} \mathrm{O}$ 1: 27-30.

Duarte, M.D., D. J. Conley, J. Carstensen \& M. SanchezCamacho, 2008. Return to Neverland: Shifting baselines effect eutrophication restoration targets. Estuaries and Coast. doi 10.1007/s12237-008-9111-2.

European Union, 2000. Directive 2000/60/EC of the European Parliament and of the Council of 23 October 2000 on establishing a framework for community action in the field of water policy. J Eur Commun L327: 1-72.

Gibson, C. E., N. J. Anderson, Q. Zhou, M. Allen \& P. G. Appleby, 2003. Changes in sediment and diatom deposition in Lower Lough Erne c. 1920-90. Biology and Environment: Proceedings of the Royal Irish Academy 103B: 31-39.

Gottschalk, M. K. E., 1975. Stormvloeden en Rivieroverstomingen in Nederland. Deel 2: de Periode 1400-1600. Assen, van Gorcum.

Gottschalk, M. K. E., 1977. Stormvloeden en Rivieroverstomingen in Nederland. Deel 3: de Periode 1600-1700. Assen, van Gorcum.

Gulati, R. D. \& S. Parma, 1982. Developments in Hydrology 11. Studies on Lake Vechten and Tjeuemeer, The Netherlands. DR W. Junk Publisher, The Hague: 383.

Gulati, R. D. \& E. van Donk, 2002. Lakes in the Netherlands, their origin, eutrophication and restoration: state of the art review. Hydrobiologia 478: 73-106.

Håkansson, H., 2002. A compilation and evolution of species in the genera Stephanodiscus, Cyclostephanos and Cyclotella with a new genus in the family Stephanodiscaceae. Diatom Research 17: 1-139.

Hausmann, S. \& F. Kienast, 2006. A diatom-inference model for nutrients screened to reduce the influence of background variables: application to varved sediments of Greifensee and evaluation with measured data. Palaeogeography, Palaeoclimatology, Palaeoecology 233: 96-112.

Hickel, B. \& H. Håkansson, 1993. Stephanodiscus alpinus in Plusssee, Germany, ecology, morphology and taxonomy in combination with initial cells. Diatom Research 8: 89-98.

Holman, I. P., M. J. Whelan, N. J. K. Howden, P. H. Bellamy, N. J. Willby, M. Rivas-Casado \& P. McConvey, 2008. Phosphorus in groundwater-an overlooked contributor to eutrophication? Hydrological Processes 22: 5121-5127.

Hordijk, C. A., 1993. Sulfur and carbon cycling in a stratifying freshwater lake. PhD thesis, Wageningen: $177 \mathrm{pp}$.

Hudson, P. F., H. Middelkoop \& E. Stouthamer, 2008. Flood management along the Lower Mississippi and Rhine Rivers (The Netherlands) and the continuum of geomorphic adjustment. Geomorphology 101: 209-236.

Juggins, S., 2007. C2 User guide. Software for ecological and palaeoecological data analysis and visualisation. University of Newcastle, Newcastle upon Tyne, UK.

Kirilova, E., O. Heiri, D. Enters, H. Cremer, A. F. Lotter, B. Zolitschka \& T. Hübener, 2009a. Climate-induced 
changes in the trophic status of a Central European lake. Journal of Limnology 68: 71-82.

Kirilova, E. P., M. van Hardenbroek, O. Heiri, H. Cremer \& A. F. Lotter, 2009b. 500 years of trophic-state history of a hypertrophic Dutch dike-breach lake. Journal of Paleolimnology. doi:10.1007/s10933-009-9371-2.

Krammer, K. \& H. Lange-Bertalot, 1991. Bacillariophyceae 4. Teil: Achnanthaceae. In Ettl., H., G. Gärtner, J. Gerloff, H. Heynig \& D. Mollenhauer (eds), Süßwasserflora von Mitteleuropa Band 2/4. Gustav Fischer Verlag, Heidelberg: $437 \mathrm{pp}$.

Krammer, K. \& H. Lange-Bertalot, 1999a. Bacillariophyceae 1. Teil: Naviculaceae. In Ettl., H., J. Gerloff, H. Heynig \& D. Mollenhauer (eds), Süßwasserflora von Mitteleuropa, Band 2/1. Gustav Fischer Verlag, Heidelberg: 876 pp.

Krammer, K. \& H. Lange-Bertalot, 1999b. Bacillariophyceae 2. Teil: Bacillariaceae, Epithemiaceae, Surirellaceae. In Ettl., H., J. Gerloff, H. Heynig \& D. Mollenhauer (eds), Süßwasserflora von Mitteleuropa, Band 2/2. Gustav Fischer Verlag, Heidelberg: 611 pp.

Krammer, K. \& H. Lange-Bertalot, 2000. Bacillariophyceae 3. Teil: Centrales, Fragilariaceae, Eunotiaceae. In Ettl., H., G. Gärtner, J. Gerloff, H. Heynig \& D. Mollenhauer (eds), Süßwasserflora von Mitteleuropa, Band 2/3. Gustav Fischer Verlag, Heidelberg: 599 pp.

Lotter, A. F., 1998. The recent eutrophication of Baldeggersee (Switzerland) as assessed by fossil diatom assemblages. The Holocene 8: 395-405.

Lotter, A. F. \& S. Juggins, 1991. POLPROF, TRAN and ZONE: programs for plotting, editing and zoning pollen and diatom data. Inqua-subcommission for the study of the Holocene, Working Group on Data-Handling Methods. Newsletter 6: 4-6.

Moss, B., 1998. Ecology of Freshwaters. Man and Medium, Past and Future. Blackwell Publishing, Oxford, UK: 557.

Neumann, T., A. Stögbauer, E. Walpersdorf, D. Stüben \& H. Kunzendorf, 2002. Stable isotopes in recent sediments of Lake Arendsee, NE Germany: response to eutrophication and remediation measures. Palaeogeography, Palaeoclimatology, Palaeoecology 178: 75-90.

Nienhuis, P. H., J. P. Bakker, A. P. Grootjans, R. D. Gulati \& V. N. de Jonge, 2002. The state of the art of aquatic and semi-aquatic ecological restoration projects in the $\mathrm{Ne}$ therland. Hydrobiologia 478: 219-233.

Portielje, R. \& D. T. van der Molen, 1998. Trend-analysis of eutrophication variables in lakes in The Netherlands. Water and Science Technology 37: 235-240.

Ramstack, J. M., S. C. Fritz, D. R. Engstrom \& S. A. Heiskary, 2003. The application of a diatom-based transfer function to evaluate regional water-quality trends in Minnesota since 1970. Journal of Paleolimnology 29: 79-94.

Rasmussen, P. \& N. J. Anderson, 2005. Natural and anthropogenic forcing of aquatic macrophyte development in a shallow Danish lake during the last 7000 years. Journal of Biogeography 32: 1993-2005.

Rigollet, C. \& R. J. de Meijer, 2002. PHAROS: a pluridetector, high-resolution, analyser of radiometric properties of soil. Nuclear Instruments and Methods in Physics Research A 488: 642-653.

Scheffer, M., 2004. Ecology of shallow lakes. Kluwer Academic Publishers, Dordrecht, The Netherlands: 357.
Shaw, R. D., J. F. H. Shaw, H. Fricker \& E. E. Prepas, 1990. An integrated approach to quantify groundwater transport of phosphorus to Narrow Lake, Alberta. Limnology and Oceanography 35: 870-886.

Smol, J. P., 2008. Pollution of Lake and Rivers: A Paleoenvironmental Perspective, 2nd ed. Blackwell Publishing, Oxford.

Steenbergen, C. L. M. \& H. Verdouw, 1982. Lake Vechten: aspeccts of its morphometry, climate, hydrology and physico-chemical characteristics. In Gulati, R. D. \& S. Parma (eds), Developments in Hydrology 11. Studies on Lake Vechten and Tjeukemeer, The Netherlands. DR W. Junk Publisher, The Hague: 383.

Stowa, 2008. Stichting toegepast onderzoek waterbeheer. Overzicht natuurlijke watertypen. STOWA rapportnummer: 2005-08, 92 pp.

ter Braak, C. J. F. \& S. Juggins, 1993. Weighted averaging partial least squares regression (WA-PLS): an improved method for reconstructing environmental variables from species assemblages. Hydrobiologia 269(270): 485-502.

ter Braak, C. J. F. \& I. C. Prentice, 1988. A theory of gradient analysis. Advances in Ecological Research 18: 271-317.

ter Braak, C. J. F. \& P. Šmilauer, 2002. CANOCO Reference Manual and User's Guide to CANOCO for Windows: Software for Canonical Community Ordination (version 4). Microcomputer Power Ithaca, New York: 351.

ter Braak, C. J. F., S. Juggins, H. J. B. Birks \& H. van der Voet, 1993. Weighted Averaging Partial Least Squares Regression (WA-PLS): Definition and Comparison with Other Methods for Species-Environmental Calibration. Elsevier Science Publishers, Amsterdam.

van Dam, H., A. Mertens \& J. Sinkeldam, 1994. A coded checklist and ecological indicator values of freshwater diatoms from the Netherlands. Netherlands Journal of Aquatic Ecology 28: 117-133.

van Donk, E., 1983. Factors influencing phytoplankton growth and succession in Lake Maarsseveen (I). PhD thesis, University of Amsterdam, The Netherlands: $148 \mathrm{pp}$.

van Donk, E., 1987. The water quality of the two Maarseveen Lakes in relation to their hydrodynamics. Hydrobiological Bulletin 21: 17-24.

van Vliet, M. T. H. \& J. J. G. Zwolsman, 2008. Impact of summer droughts on the water quality of the Meuse River. Journal of Hydrology 353: 1-17.

van der Molen, D. T. \& P. C. M. Boers, 1999. Eutrophication control in the Netherlands. Hydrobiologia 395(396): 403409.

Vannote, R. L., G. W. Minshall, K. W. Cummins, J. R. Sedell \& C. E. Cushing, 1980. The river continuum concept. Canadian Journal of Fisheries and Aquatic Sciences 37: 130-137.

Walker, B. \& J. A. Meyers, 2004. Thresholds in ecological and social-ecological systems: a developing database. Ecology and Society. http://www.ecologyandsociety.org/vol9/ iss $2 / \operatorname{art} 3 /$.

Wetzel, R. G., 2001. Limnology. Academic Press, San Diego.

Wolf, J., A. H. W. Beusen, P. Groenendijk, T. Kroon, R. Rötter \& H. van Zeijts, 2003. The integrated modelling system STONE for calculating nutrient emissions from agriculture in the Netherlands. Environmental Modelling and Software 18: 597-617. 